\title{
Strategies to optimize the practice of dental impression during the Covid-19 pandemic
}

\author{
Estratégias para otimizar a prática da impressão \\ dental durante a pandemia do Covid-19
}

\author{
Viviane Maria Gonçalves de FIGUEIREDO' ${ }^{\text {iD }}$ https://orcid.org/0000-0003-4657-0984 \\ Manassés Tercio Vieira GRANGEIRO² iD https://orcid.org/0000-0003-0955-0968 \\ Gregorio Marcio de Figueiredo RODRIGUES ${ }^{3}$ iD https://orcid.org/0000-0002-9881-025X
}

\section{ABSTRACT}

The Covid-19 is a global health threatening pandemic, so dental surgeons need to look for strategies to perform dental care safely for the patient, the dental professional himself, and the dental team. The goal is to design strategies to optimize dental impression practice during the Covid-19 pandemic. The strategies that optimize dental impression practice during the pandemic are to adopt the digital fingerprint workflow. If necessary, a conventional impression technique that favors the professional's performance, select the impression material that is easy to decontaminate and affinity for the professional; the plaster leak must be performed still inside the dental office, and then the disinfection of the plaster model must be previously sent to the prosthesis laboratory.

Indexing terms: Containment of biohazards. Coronavirus infections. Dentistry.

\section{RESUMO}

A Covid-19 é uma pandemia que ameaça de saúde global, assim os cirurgiões-dentistas necessitam buscar estratégias para realizar o atendimento odontológico de forma segura para paciente, próprio profissional e equipe odontológica. Objetiva-se traçar estratégias que otimize a prática da impressão dental durante a pandemia da Covid-19. As estratégias que otimizam a prática da impressão dental, durante a pandemia, são adotar o fluxo de trabalho digital através da impressão digital. Caso necessário a impressão convencional, uma técnica de impressão que favoreça o desempenho do profissional, selecionar o material de moldagem de fácil descontaminação e de afinidade pelo profissional; o vazamento do gesso deve ser realizado ainda dentro do consultório odontológico, e em seguida a desinfecção do modelo em gesso previamente ser enviado ao laboratório de prótese.

Termos de indexação: Contenção de riscos biológicos. Infecções por Coronavirus. Odontologia.

\section{$\boldsymbol{\nabla v} \boldsymbol{\nabla v}$}

1 Universidade Federal de Pernambuco, Departamento de Prótese e Cirurgia Buco-Facial. Av. Prof. Moraes Rego, 1235, 50670-901, Cidade Universitária, Recife, PE, Brasil. Correspondence to: VMG FIGUEIREDO. E-mail: <vivi_mfigueiredo@yahoo.com.br>.

2 Universidade do Estado de São Paulo, Instituto de Ciência e Tecnologia, Departamento de Materiais Dentários e Prótese. São José dos Campos, SP, Brasil.

3 Universidade Federal da Paraíba, Programa de Pós-Graduação em Odontologia. João Pessoa, PB, Brasil.

$\boldsymbol{\nabla} \mathbf{v} \boldsymbol{v}$

How to cite this article

Figueiredo VMG, Grangeiro MTV, Rodrigues GMF. Strategies to optimize the practice of dental impression during the Covid-19 pandemic. RGO, Rev Gaúch Odontol. 2021;69:e2021015. http://dx.doi.org/10.1590/1981-86372021001520200132 


\section{INTRODUCTION}

An outbreak of new coronavirus-transmitted disease (COVID-19) in China changed the living conditions of the population in several countries [1], and caused widespread public health problems [2], becoming a global health threat [3]. Despite global efforts to contain the spread of the disease, the outbreak is still increasing due to the community's pattern of spread of this infection [2].

Once in the human body, this coronavirus becomes present in the nasopharyngeal and salivary secretions of affected patients, and its spread is believed to be predominantly a drop or respiratory contact in nature [2]. Among health professionals, dentists are exposed to a higher risk of being infected due to close contact with infected patients [2].

Due to the rapidly evolving disease situation, a more thorough assessment of the implications of the Covid-19 outbreak on dental practice is required [4], as in emergency care conditions involving prosthetic procedures. As explained above, the objective is to design strategies to optimize dental impression practice during the Covid-19 pandemic.

\section{SARS-COVID-19}

The new Sars-Cov-2 (Covid-19), provided with a seafood market in the city Wuhan province of Hubei in China, has caused severe pneumonia and spread rapidly to other provinces in China and other countries $[5,6]$. This is a zoonotic infection, similar to other coronavirus infections, if believed to have originated in bats and subsequently transmitted to humans [2].

Covid-19 person-to-person transmission routes include direct transmission such as coughing, sneezing, droplet inhalation and aerosol transmission [4-6] contact transmission such as contact with oral, nasal and ocular mucosa. Covid-19 can also be transmitted through saliva, and oral-fetal routes [5].

With the spread of the disease in several countries and continents, the World Health Organization has declared a pandemic situation, among the diseases associated with this disease are high mortality rate, which can reach $8 \%$, and transmission [7]. Restrictive measures to limit transmission have been taken in several countries, and the importance of infection control is therefore crucial in limiting the effects of virus spread [7]. Since its emergence in December 2019, coronavirus disease 2019 (VOCID-19) has affected several countries, affecting more than 90,000 patients and making it a global public threat.

The Covid-19 is present in saliva samples from infected individuals; saliva is therefore a potential source of infection for both professionals and dental patients, given the possible transmission routes involving aerosol, spatter or droplets containing saliva [8].

\section{Dental practices}

With the pandemic situation by Covid-19 dentists were instructed by regulatory authorities, such as the American Dental Association, to discontinue dental treatment of patients, except those in emergency condition. For the purpose of personal protection, their families, contacts and patients against transmission of the virus, in addition to preserving the necessary supplies of personal protective equipment (PPE) [7].

Dental surgeons and staff involved in dental practice are exposed to a high risk of infection by Covid-19 due to face-to-face communication and exposure to saliva, blood and other body fluids, and handling of sharp instruments [5]. A sudo evaluated anxiety and fear of becoming infected among dentists while working during the current coronavirus outbreak, an online questionnaire was applied from March 10-17, 2020, in 30 different countries around the world. The findings were $78 \%$ of general practitioners were anxious and scared of the devastating effects of the disease, $90 \%$ of dentists were aware of the changes in treatment protocols, yet only $61 \%$ of professionals recorded the implementation of the altered treatment protocol [1].

Most dental procedures generate significant amounts of droplets and aerosols, which pose potential risks of infection transmission. Therefore, in addition to standard precautions, special precautions should be implemented during the Covid-19 pandemic [3]; several dental practices were modified in accordance with recommended guidelines for emergency treatment only or closed practices for an uncertain period [1]. As well, disinfection of the clinical environment should be preserved by adopting effective and rigorous measures according to the protocol in force in the country [5].

Cross infection control should be applied at all times and social distancing should be adopted in practice. Most 
dental procedures generate aerosol; such as preparation of cavities, use of rotating instruments in preparation of canals, finishing and polishing of restorations, dental implant and oral surgeries; making the condition of dental practice delicate. Because an asymptomatic patient with Covid-19 may seek emergency dental treatment; therefore these patients will have saliva contaminated with the virus, in addition to the connective mucosa and upper respiratory tract connected by the nasolacrimal duct which are a confirmed source of infection [7].

There is still no consolidation of a treatment protocol or vaccine for this disease [6], in view of the scenario it would be important for dentists to perform procedures that do not generate aerosols from their patients, such as curettage of carious lesions and manual instrumentation in endodontic procedures. Identify virusrelated oral symptoms, such as taste abnormality, adopt the practice of teleodontology previously in cases of dental emergency, advice on the use of drugs for oral treatment and advise against self-medication [7].

New studies should focus on developing barrier techniques and negative pressure procedures to contain and isolate the aerosol so that dental procedures are safe for the healthcare professional and patients [7]. At this critical time, the provision of dental services must take into account the availability of IPE, and that only emergency cases are admitted for treatment [7].

Thus, dentists should be updated on how this pandemic is related to their profession in order to be well guided and prepared in terms of prevention, treatment and clinical orofacial manifestations [6,7]. Understanding the meaning of aerosol transmission and its implications for dentistry can facilitate the identification and correction of neglect in daily dental practice [3]. National and international guidelines should be proposed by regional and national dental associations, and sent to all dentists registered during a crisis, including the VOCID-19 pandemic, to ensure that these professionals are well informed and aware of best practices and recommended approaches to disease management [9].

It is important to highlight the role of the surgeon-dentist also in fighting the pandemic, as he is a professional with experience in infection control and barrier techniques [7] he should be vigilant in defending against the spread of VOCID-19 [6]. The provision of oral health care should protect their patients and dental team members, it is necessary that these team professionals are well acquainted with the transmission of Covid-19 and preventive measures $[6,7]$

\section{Dental impression}

Dental emergency situations such as crown fractures, fixed bridges, removable prosthesis or dental prosthesis where the patient needs to replace the missing dental element or the prosthetic appliance, due to masticatory, occlusal, phonetic, aesthetic and social issues. In other words, these are clinical situations in which there will be a need for immediate dental intervention, and during the prosthetic replacement the impression of the reagion to be rehabilitated will be added. However, the treatment of prosthetic rehabilitation because it involves several clinical stages, can promote cross infection and viral contamination inside and outside the dental office, as an example through the impressions of dental arches or regions [10]. In the chain of contamination, besides the patient, dental team and dental surgeon; cross contamination can also occur among professionals who deliver to the prosthetic laboratories and among the employees of the prosthetic laboratory (figure 1).

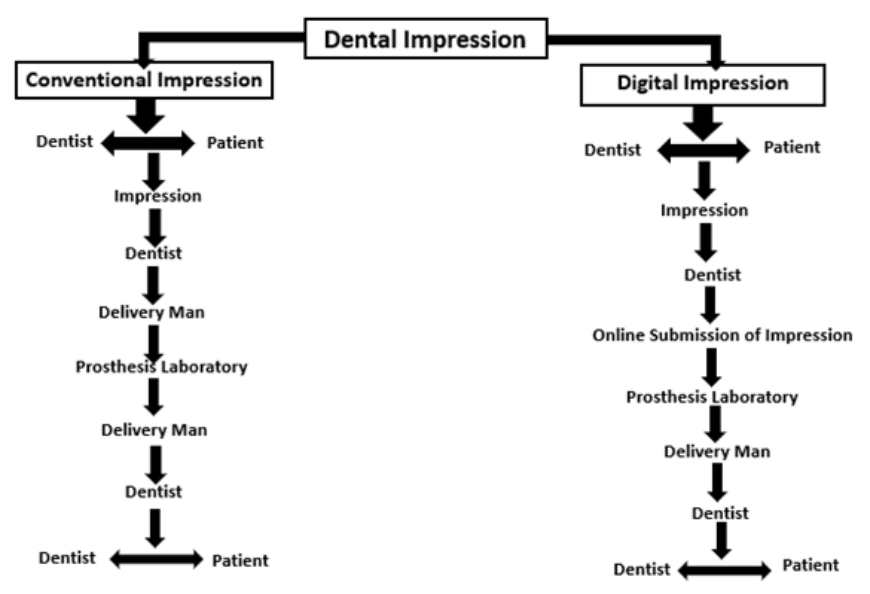

Figure 1. Conventional Impression: Dentist performs the impression on the patient, then forwards the impression to the prosthesis laboratory through the delivery man. After the work is done, the prosthesis lab sends it to the dentist, through the delivery man, the dentist receives the final work and installs it in the patient. Digital impression: Dentist scans the patient, sends online the impression to the prosthesis lab. After the work is done, the prosthesis lab sends it to the dentist, through the delivery man, the dentist receives the final work and installs it in the patient. 
There are reports in the literature that during the Covid-19 pandemic there was a significant reduction in prosthetic works compared to the same period in 2019, in addition to the reduction in clinical work time and number of consultations. The fully digital workflow was implemented compared to the conventional workflow [10].

By performing dental impressions in a conventional way, patients' biological fluids (saliva or blood) are present and serve as a source of contamination among professionals involved in this action; in addition to droplets and aerosols containing SARS-CoV-2 generated during the procedure [10]. The virus can survive in a humid environment until the impression arrives at the prosthesis laboratory; and when this impression is not disinfected it can transmit the virus to the plaster models, consequently to the professionals of the prosthesis laboratory [10].

This scenario of transportation between the dental office and the prosthesis laboratory was already a matter of concern for the dental community, as there were already limitations on infection prevention procedures. Transport of impressions to dental laboratories is often delayed, and with limited precautions to avoid cross infection. Plaster casts are often contaminated, especially by bacteria that have antibiotic-resistant strains; and some disinfectant solutions are irritating or non-ecologic. Guidelines for infection prevention in dentistry have been published by the Centers for Disease Control and Prevention since 2003, but have not been modernized in later versions to meet the needs of traditional, computer-aided technology [11].

An alternative to minimize virus transmission would be the use of fingerprints [10], although the tip of the scanner is inserted in the mouth may be contaminated with the patient's saliva and droplets, this tip is sterilizable according to the manufacturer's recommendations. As every workflow is digital, it eliminates from the contamination chain the professionals who deliver to the laboratories and among the employees of the prosthesis laboratory. The prosthesis laboratory receives the scanned image, which is virtually sent to the prosthetic part manufacturing system by Computer-aided design/Computer-aided manufacturing (CAD/CAM).

The digital impression is an interesting way to capture the image of the area of interest or dental arch, safely and comfortably for patients, and can be more accurate than traditional printing. An advantage is the easier prevention of infection, since mostly fingerprints are not a source of cross infection, since the patient may present asymptomatic for an already existing disease, the transport of contaminated items is reduced and limited to the stages of testing or proof; besides there is no aspiration of particles, mucous irritation. However, the disadvantages are that the file is unalterable, but may be ruined by a computer virus, need for costly investment in compoters, softwer, scanner. In addition, the reconditioning of the scanner tips is determinant optical characteristics and long-term use of the scanner, but the information for reconditioning of producers is generally limited [11].

A limitation of fingerprints are in the making of conventional total prosthesis where there will be a need for conventional printing. In cases of partial removable prosthesis there are some systems that favor the capture of the model imitation in plaster or even intra-oral in the patient to make the metallic infrastructure; however it is not a reality among all dental professionals today.

The COVID-19 is a major emergency worldwide, which should not be underestimated. Due to the rapidly evolving situation, a more thorough assessment of the implications of the Covid-19 outbreak on dental practice is required [4]. Since dental professionals are aware of this transmission chain, they should take protective measures [8] and prevent the spread of the disease [2].

In cases of prosthetic emergencies, immediate procedures such as making provisional prostheses should be chosen. When there is a need for a dental impression, in case it is not possible to do the conventional impression, a technique that favors the professional's performance should be used. And the selection of the conventional impression material should be easy to decontaminate, of affinity for the professional to avoid the repetition of the procedure and the leaking of the plaster should still be carried out inside the dental office, in order to avoid the cross contamination with the professional who makes the delivery and with the prosthesis laboratory. Remembering that the plaster models, sent to the prosthesis laboratory, must be previously disinfected.

Future studies should observe the effectiveness of the methods of disinfection of the moulding materials, present in the literature, in front of the Covid-19 so that it is possible for the dental surgeon to perform his work safely. Business strategies should favor the acquisition of fingerprint scanners by dental professionals, which in addition to reducing the chace of contamination and transmission of infections, would promote the transition from conventional to digital dentistry. 


\section{Concluding remarks}

The strategies that optimize the practice of dental impression, during the Covid-19 pandemic, are to adopt the digital workflow through the fingerprint. If necessary the conventional impression, a printing technique that favors the professional's performance, select the molding material that is easy to decontaminate and affinity by the professional; the plaster leak must be performed still inside the dental office, and then the disinfection of the model in plaster be previously sent to the prosthesis laboratory.

\section{Collaborators}

VMG FIGUEIREDO got the idea of the article, researched the literature and wrote the article. MTV GRANGEIRO wrote and structured the article. GMF RODRIGUES structured the article.

\section{REFERENCES}

1. Ahmed MA, Jouhar R, Ahmed N, Adnan S, Aftab M, Zafar MS, Khurshid, Z. Fear and - Practice Modifications among Dentists to Combat Novel Coronavirus Disease (COVID-19) Outbreak. Int J Environ Res Public Health. 2020;17(8):2821. https://doi.org/10.3390/ijerph17082821

2. Ather A, Patel B, Ruparel NB, Diogenes A, Hargreaves KM. Coronavirus Disease 19 (COVID-19): Implications for Clinical Dental Care. J Endod. 2020;46(5):584-595. https://doi. org/10.1016/j.joen.2020.03.008

3. Ge ZY, Yang LM, Xia JJ, Fu XH, Zhang YZ. Possible aerosol transmission of COVID-19 and special precautions in dentistry. J Zhejiang Univ Sci B. 2020;21(5):361-368. https:// doi.org/10.1631/jzus.B2010010
4. Izzetti R, Nisi M, Gabriele M, Graziani F. COVID-19 transmission in dental practice: brief review of preventive measures in Italy. J Dent Res. 2020;99(9):1030-38. https://doi. org/10.1177/0022034520920580

5. Peng $X, X u X, L i Y$, Cheng $L$, Zhou $X$, Ren B. Transmission routes of 2019-nCoV and controls in dental practice. Int J Oral Sci. 2020;12(1):1-6. https://doi.org/10.1038/s41368-020-0075-9

6. Fini MB. What dentists need to know about COVID-19. Oral Oncol. 2020;105:104741. https://doi.org/10.1016/j. oraloncology.2020.104741

7. Dar Odeh N, Babkair H, Abu-Hammad S, Borzangy S, AbuHammad A, Abu-Hammad O. COVID-19: present and future challenges for dental practice. Int J Environ Res Public Health. 2020;17(9):3151. https://doi.org/10.3390/ijerph17093151

8. Schwendicke F. Saliva is a potential source of Covid-19, and appropriate protection measures should be applied in dental practice. Evid Based Dent. 2020;21(2):62. https://doi. org/10.1038/s41432-020-0101-y

9. Khader Y, Al Nsour M, Al-Batayneh OB, Saadeh R, Bashier $H$, Alfaqih M, Al-Azzam S. Dentists' awareness, perception, and attitude regarding COVID-19 and infection control: crosssectional study among Jordanian dentists. JMIR Public Health Surveill. 2020;6(2):e18798. https://doi.org/10.2196/18798

10. Papi P, Di Murro B, Penna D, Pompa G. Digital prosthetic workflow during COVID-19 pandemic to limit infection risk in dental practice. Oral Dis. 2021;27(Suppl 3):723-726. https:// doi.org/10.1111/odi.13442

11. Barenghi L, Barenghi A, Cadeo C, Di Blasio A. Innovation by computer-aided design/computer-aided manufacturing technology: a look at infection prevention in dental settings. BioMed Res Int. 2019. https://doi.org/10.1155/2019/6092018

Received on: 29/7/2020

Final version resubmitted on: 13/12/2020 Approved on: 18/1/2021 